\title{
Unit Energy Consumption as Benchmark to Select Energy Positive Retrofitting Strategies for Finnish Wastewater Treatment Plants (WWTPs): a Case Study of Mikkeli WWTP
}

\author{
Khum Gurung $^{1}$ (D) Walter Z. Tang ${ }^{2} \cdot$ Mika Sillanpää $^{1}$
}

Received: 21 January 2018 / Accepted: 21 May 2018 / Published online: 7 June 2018

(C) The Author(s) 2018, corrected publication 2018

\begin{abstract}
Retrofitting municipal wastewater treatment plants (WWTPs) to energy positive is a major challenge faced by many water utilities. Selection of innovative technologies to achieve retrofitting goals is critical for capital improvement programs in WWTPs. This paper aims to provide a statistical analysis method of unit energy consumption in conventional Finnish WWTPs, presenting Mikkeli WWTP as a case study. The average energy consumption at Finnish WWTPs was quantified as a mean of $0.49 \mathrm{kWh} / \mathrm{m}^{3}$ with a standard deviation of 0.197 . The statistical analysis showed that the total energy consumption in Finnish WWTPs are positively correlated with inflow rate and sludge production. However, the unit energy consumption decreases with increasing plant capacity. The energy benchmarking of Mikkeli WWTP confirmed the energy gap of $0.11 \mathrm{kWh} / \mathrm{kg}$ COD in electricity. The major energy saving potentials are attributed to secondary treatment, screening and grit removal, and influent pump stations. A plausible innovative retrofitting strategy comprising four emerging energyneutral or positive technologies is proposed to maximally harness the chemical energy content in wastewater: enhanced primary sedimentation, staged anaerobic fludized membrane bioreactor (SAF-MBR) with completely autotrophic nitrogen removal over nitrite process (CAN$\mathrm{ON}$ ), and co-digestion of sludge with organic food-waste. The net energy balance of emerging technologies showed a maximum energy saving potential of $1.26 \mathrm{kWh} / \mathrm{kg} \mathrm{COD}$, which could be sufficient to overcome the energy gap of Mikkeli WWTP, providing net positive energy surplus of $1.15 \mathrm{kWh} / \mathrm{kg}$ COD.
\end{abstract}

The original version of this article was revised due to a retrospective Open Access order

\section{Khum Gurung}

khumgrg@yahoo.com

1 Laboratory of Green Chemistry, School of Engineering Science, Lappeenranta University of Technology, Sammonkatu 12, FI-50130 Mikkeli, Finland

2 Department of Civil and Environmental Engineering, Florida International University, Miami, FL 33174, USA 
Keywords Municipal WWTPs · Energy consumptions · Energy benchmarking · Innovative energy positive retrofitting strategies

\section{Introduction}

Municipal WWTPs, which typically employ conventional activated sludge (CAS) processes, are intensive energy consumers (Dai et al. 2015; Daw et al. 2012; Gikas 2017; Shoener et al. 2014; Yan et al. 2017). WWTPs consume 30 to $60 \%$ of municipal energy demand (Scherson and Criddle 2014). The specific energy consumption of CAS plants generally ranges from 0.3 to $0.6 \mathrm{kWh} / \mathrm{m}^{3}$, of which about half is used for aeration to supply $\mathrm{O}_{2}$ and convert organic pollutants to sludge (Dai et al. 2015; Scherson and Criddle 2014; Shoener et al. 2014). In the European Union (EU), the energy requirements in WWTPs account for more than $1 \%$ of the consumption of electricity in Europe (EU 2017). In the United States, wastewater treatment demands approximately $4 \%$ of the nation's electricity ( 75 billion $\mathrm{kWh}$ ) (USEPA 2010), whereas the energy consumed by WWTPs in China is 100 billion kWh of electricity (Yan et al. 2017). About $\$ 7.5$ billion is required annually to cover the electricity cost to deliver safe drinking water and provide effective wastewater treatment in the US (USEPA 2010). Over the next 20 years, the US water and wastewater infrastructures will require a huge investment of about $\$ 600$ billion for treating and transferring water and wastewater (EPA 2015). The electricity demand to operate WWTPs will increase by more than $20 \%$ in the next 15 years in the developed countries, contributing to climate change via green house gas (GHG) emissions due to the use of fossil fuels in power plants (Hao et al. 2015; Wang et al. 2012). If the current trend is to be continued, massive natural resource depletion, environmental risks, and substantial economic expenditures will be intensified (Yan et al. 2017). Therefore, sustainable wastewater treatment technologies are of prime interest to reduce the substantial amount of energy consumption and carbon footprints in WWTPs.

There are various methodologies to estimate energy consumption in WWTPs. Energy benchmarking in WWTPs is a powerful management tool which uses statistical data to determine the energy efficiency of a plant in comparision with other plants or standard benchmarks (Belloir et al. 2015), in an effort to achieve energy savings. Energy benchmarking can be an internal process, measuring WWTP performance against its own past performance, or an external process, comparing to the benchmarks of similar WWTPs. Poorly performing wastewater treatment facilities can be prioritized for immediate improvement. Nevertheless, the energy benchmarking methodology can be of limited use when comparing similar WWTPs in different locations, because of the different influent wastewater pollution loads, COD/N ratios, and effluent consents (Belloir et al. 2015). Even though it is very challenging to compare energy consumption across different locations, some common trends in energy consumption have been reported by previous benchmarking studies: unit electricity consumption decreases as the size of the plant increases. These processes include aeration, sludge treatment and pumping stations which are the most electricity demanding processes (Belloir et al. 2015). Energy consumption in WWTPs involves various forms of energy such as electrical, manual, fuel, chemical etc. Electrical energy is only about half of the total energy consumption in a wastewater treatment process (Singh et al. 2012).

To achieve energy positive wastewater treatment, increasing numbers of cutting edge technologies, such as enhanced primary separation by diverting BOD to anaerobic digestion, biological removal of ammonia through anammox, anaerobic digestion (AD), biological 
microbial fuel cells (MFCs), microalgae cultivation processes have been commercially implemented (Dai et al. 2015; Hahn and Figueroa 2015; McCarty et al. 2011; Meerburg et al. 2015; Remy et al. 2014; Scherson and Criddle 2014). So far, anaerobic digestion (AD) is considered as the key technology to create net-zero energy WWTPs via recovery of organic chemical energy to electricity or heat (Gao et al. 2014; McCarty et al. 2011; Yan et al. 2017). The energy self-sufficiency via AD treatment of wastewater has been realized partially $(\sim 30 \%)$ or fully $(\sim 100 \%)$ in many WWTPs (McCarty et al. 2011; Shen et al. 2015; Yan et al. 2017). With an enhanced primary treatment process using microsieving facilities, about $54-85 \%$ of energy reductions (net energy balance of $0.115-0.32 \mathrm{kWh} / \mathrm{m}^{3}$ ) have been reported (Gikas 2017; Remy et al. 2014). A net-zero energy (NZE) model (Yan et al. 2017), based on the adjustment of metabolic material allocation, showed about $80 \%$ offsetting of electricity and sludge disposal cost as compared to conventional WWTPs. Mainstream short-cut nitrogen removal techniques (e.g., CANON with anammox) showed excellent net energy balance of $0.09-0.23 \mathrm{kWh} / \mathrm{m}^{3}$ (Dai et al. 2015; Scherson and Criddle 2014). A pilot-scale anaerobic baffled reactor (ABR) as enhanced primary treatment in psychrophilic conditions showed excellent net electrical energy potential of $0.15-0.24 \mathrm{kWh} / \mathrm{m}^{3}$ (Hahn and Figueroa 2015). To further enhance biogas production through $\mathrm{AD}$ process, activated-sludge was co-digested with fat-oil-grease (FOG) to provide 30 to $100 \%$ more biogas production (Lauwers et al. 2012).

The main objective of this paper is to perform a statistical analysis of energy consumption in Finnish municipal WWTPs and to assess retrofitting strategies for the Mikkeli WWTP as a case study. A major energy gap in Mikkeli WWTP (case study) was quantified by comparing with the unit energy consumption benchmarks. An innovative configuration comprising four emerging technologies, i.e., (1) enhanced primary sedimentation, (2) staged anaerobic fluidized membrane bioreactor (SAF-MBR), (3) completely autotrophic nitrogen removal over nitrite process (CANON), and (4) co-digestion of sewage sludge with organic waste, were evaluated for their feasibility to achieve energy self-sufficiency at the Mikkeli WWTP.

\section{Database and Methods}

\subsection{Database}

The database for unit energy consumption at various WWTPs was critically reviewed and extracted from extensive peer-reviewed and original research papers (Dong et al. 2017; Gu et al. 2017; Rodriguez-Garcia et al. 2011; Wang et al. 2012; Yan et al. 2017). Various guideline manuals for energy positive WWTPs from the Environmental Protection Agency (EPA), the Water Environment Research Foundation (WERF), the Water Environment Foundation (WEF) (Crawford and Sandino 2010; Daw et al. 2012; Fillmore et al. 2011; Goldstein and Smith 2002; Tarallo et al. 2015; USEPA 2010; Wisconsin 2016) were reviewed. Moreover, peer-reviewed articles for energy-neutral or positive emerging technologies were analyzed for theoretical data and net energy savings calculations (Ali and Okabe 2015; Dai et al. 2015; Gao et al. 2014; Kartal et al. 2010; Katuri et al. 2014; Kim et al. 2011; Lauwers et al. 2012; McCarty et al. 2011; Meerburg et al. 2015; Nowak et al. 2015; Remy et al. 2014; Scherson and Criddle 2014; Shen et al. 2015; Shoener et al. 2014; Yoo et al. 2012). IBM SPSS software was used in statistical analysis and regression analysis. The theoretical data used inthis study are summarized in Table 1. 
Table 1 Theoretical data used for energy estimations

\begin{tabular}{|c|c|c|c|}
\hline Description & Unit & Value & References \\
\hline $\begin{array}{l}\text { Max. theoretical energy potential in } \\
\text { medium strength US wastewater }\end{array}$ & $\mathrm{kWh} / \mathrm{m}^{3}$ & 1.96 & McCarty et al. 2011 \\
\hline $\begin{array}{l}\text { Energy content of domestic } \\
\text { wastewater (COD basis) }\end{array}$ & $\mathrm{kJ} / \mathrm{g}$ COD & 13.5 & Metcalf and Eddy 2003 \\
\hline Methane content of biogas yield & $\%$ & $60-70$ & Kim et al. 2011 \\
\hline $\begin{array}{l}\text { Per capita COD load in } \\
\text { municipal wastewater }\end{array}$ & g COD/capita/day & 120 & Nowak et al. 2015 \\
\hline Energy yield from methane combustion & $\mathrm{kWh} / \mathrm{mol} \mathrm{CH}_{4}$ & 0.222 & Yoo et al. 2012 \\
\hline
\end{tabular}

The benchmarking analysis of electricity consumption in Finnish municipal WWTPs were assessed from a previously conducted survey database that was based on a questionnaire of large (> 100,000 PE), medium-sized (30,000-100,000 PE), and small-scale WWTPs (Haimi et al. 2009). The following information was asked in the questionnaire: influent flow rate; influent and effluent orgnic loads; dosing capacity; population served; type of sewerage system; and electricity consumption. Furthermore, on-site survey of the Mikkeli WWTP was made and information was collected as a case study. 22 municipal WWTPs, including the case study WWTP, were evaluated based on their scales and electricity consumption. The selected WWTPs comprised activated sludge facilities with different configurations and capacities. Among them, fourtneen plants were designed for total nitrogen removal, six (including the case study plant) for ammonial removal, and two plants for biological phosphorus removal. Though the total energy consumption for WWTPs is the sum of electrical, manual, mechanical and chemical energy consumptions, this paper focuses on the electrical energy consumption. Two relevant unit energy consumption indicators were calculated, as follows:

1) Energy consumption per unit of treated wastewater $\left[\frac{\mathrm{kWh}}{\mathrm{m}^{3}}\right]=\frac{\text { Energy Consumption }\left(\frac{\mathrm{kWh}}{\mathrm{d}}\right)}{\text { Treated wastewater }\left(\frac{\mathrm{m}^{3}}{\mathrm{~d}}\right)}$

2) Energy consumption per unit COD removed $\left[\frac{\mathrm{kWh}}{\mathrm{kg} \mathrm{COD}}\right]=\frac{\text { Energy Consumption }\left(\frac{\mathrm{kWh}}{\mathrm{d}}\right)}{\text { COD removed }\left(\frac{\mathrm{kg} \mathrm{COD}}{\mathrm{d}}\right)}$

\section{Results and Discussion}

\subsection{Current Electricity Consumption in Finnish WWTPs}

The unit energy consumption of 22 WWTPs were statistically analyzed to present the current energy use in Finnish WWTPs. The histogram of unit energy consumption of the Finnish WWTPs is depicted in Fig. 1. The unit energy consumption in the Finnish WWTPs ranges from 0.18 to $0.96 \mathrm{kWh} / \mathrm{m}^{3}$. The observed data are comparable to unit energy consumption in conventional activated sludge process in Japanese WWTPs (Mizuta and Shimada 2010). The mean energy consumption value is quantified at $95 \%$ confidence interval as $0.49 \pm 0.197 \mathrm{kWh} /$ $\mathrm{m}^{3}$ varying between 0.39 and $0.57 \mathrm{kWh} / \mathrm{m}^{3}$. The statistical data confirms that the current trend of energy consumptions in Finnish WWTPs is energy intensive.

Similarly, the total energy consumption of Finnish WWTPs was expressed as kWh/year with an immediate estimation of the annual bill. The regression analysis of total energy consumption was assessed with respect to different plant scales and amount of sludge produced as shown in 


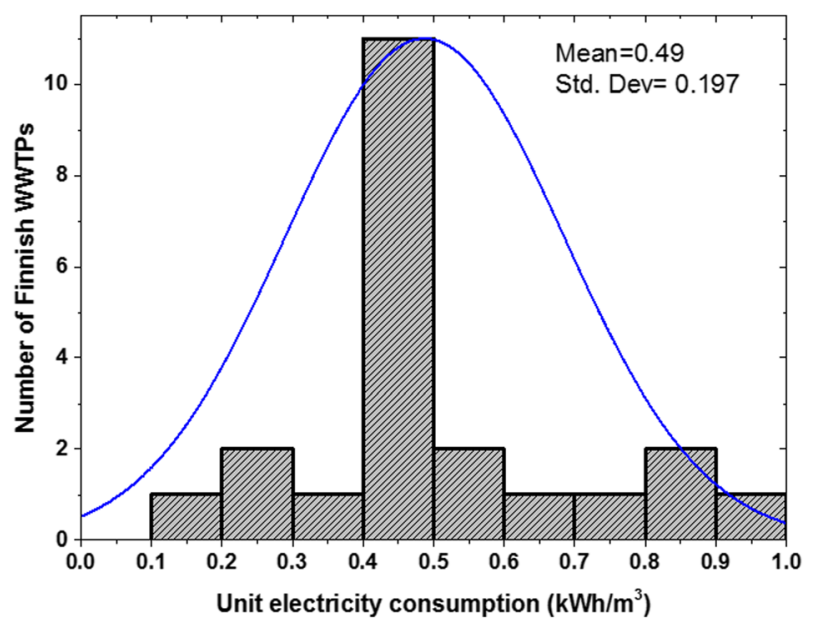

Fig. 1 Histogram of unit energy consumption in Finnish municipal WWTPs

Fig. 2. The total energy consumption increases with increasing influent load, i.e., the scale of the WWTP (Fig. 2a). Similar trend of energy consumption has been reported by others (Vaccari et al. 2018). Likewise, the increasing sludge production also increases the total energy consumption (Fig. 2b). An average sludge production of about $1.2 \mathrm{~kg} \mathrm{TS} / \mathrm{kg} \mathrm{BOD}$ was observed, with water content varying from 68 to $94 \%$ (Haimi et al. 2009). Therefore, sludge handling processes including thickening, anaerobic digestion and dewatering (centrifugation) consume significant energy. The large amount of sludge production from the secondary treatment process and the
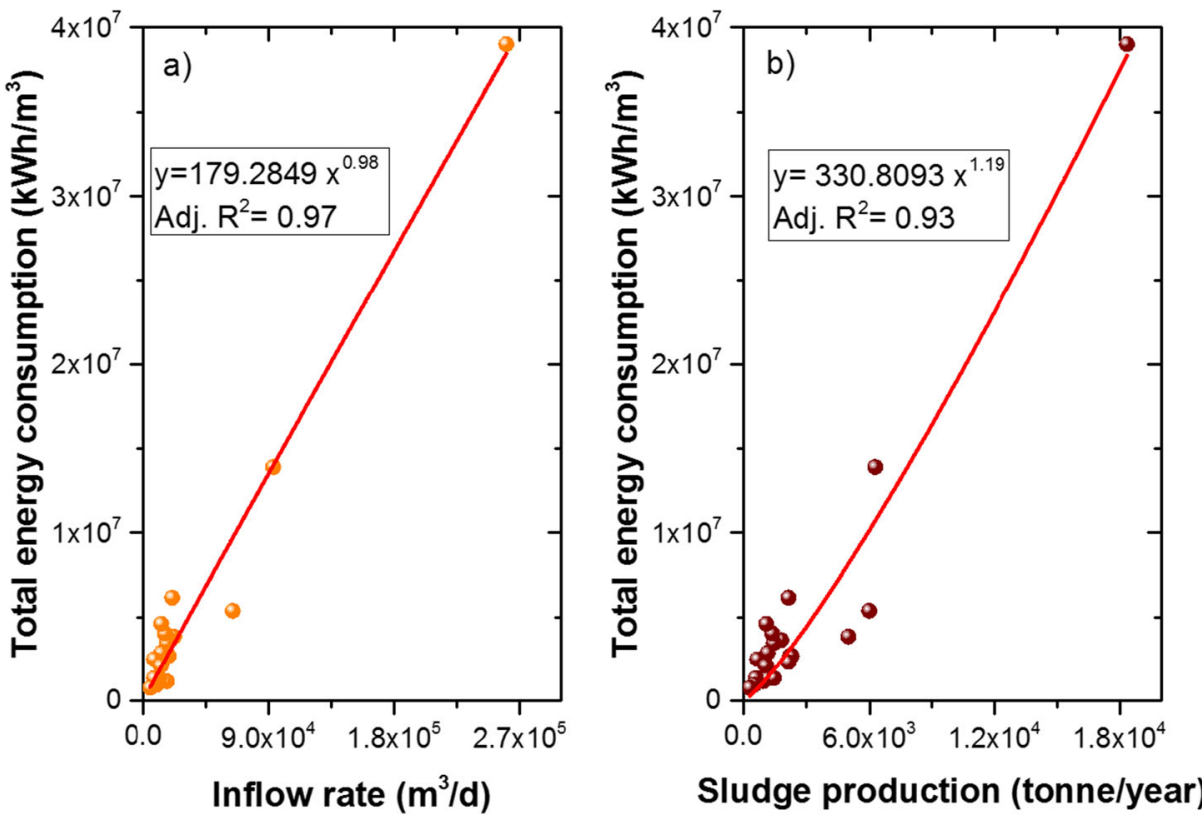

Fig. 2 Total energy consumption as function of: (a) daily inflow rate (annual average); and (b) sludge production (annual average) 
energy consumptions are the major issues in most of the CAS processess worldwide (Tang and Sillanpää 2018). Moreover, the fitting of the observed data with a power law gives a good correlation of total energy consumption to influent flow rate and sludge production with regression coefficients $\left(\mathrm{R}^{2}\right)$ of 0.97 and 0.93 , respectively.

The distribution of unit energy consumption in Finnish WWTPs is depicted in Fig. 3. The unit energy consumption of WWTPs with flow rate of $<20,000 \mathrm{~m}^{3} / \mathrm{d}$ is highly fluctuating and ranging from 0.18 to $0.96 \mathrm{kWh} / \mathrm{m}^{3}$. Similar trendency of unit energy consumption has been reported in Slovakian municipal WWTPs (Bodík and Kubaská 2013). The smaller WWTPs are characterized by a high energy consumption compared to relatively larger-scale WWTPs. Even though small-scale WWTPs have simplified configuration and wastewater and sludge handling processes, the unit energy consumption is greater than larger WWTPs due to less frequent optimizations and hurdles associated with simplified management (Foladori et al. 2015).

The unit energy consumption as function of plant scale of Finnish WWTPs is compared with worldwide small to large-scale WWTPs, as shown in Table 2. The unit energy consumption decreases substantially when plant scales increase from $3800 \mathrm{~m}^{3} / \mathrm{d}$ to greater than $378,500 \mathrm{~m}^{3} / \mathrm{d}$, which confirms the economy of scale (Vaccari et al. 2018).

\subsection{Energy Self-Sufficiency at Mikkeli WWTP}

\subsubsection{Description of Mikkeli WWTP}

The Mikkeli WWTP employs the CAS process, and treats about $5 \times 10^{6} \mathrm{~m}^{3} /$ year of wastewater (Gurung et al. 2016). The aeration plants are equipped with fine-bubble aeration and mixing devices. The treatment plant was in operation since the 1960s and the only process optimizations were performed by changing and upgrading the mechanical devices.

Table 3 shows the annual wastewater load, COD removal efficiency, sludge production from aeration (secondary) treatment, and corresponding energy consumption of the case study plant. The following operational data from 2007 to 2016 were obtained, showing mean influent load of about 63,506 PE. No significant changes in the treated wastewater flow,

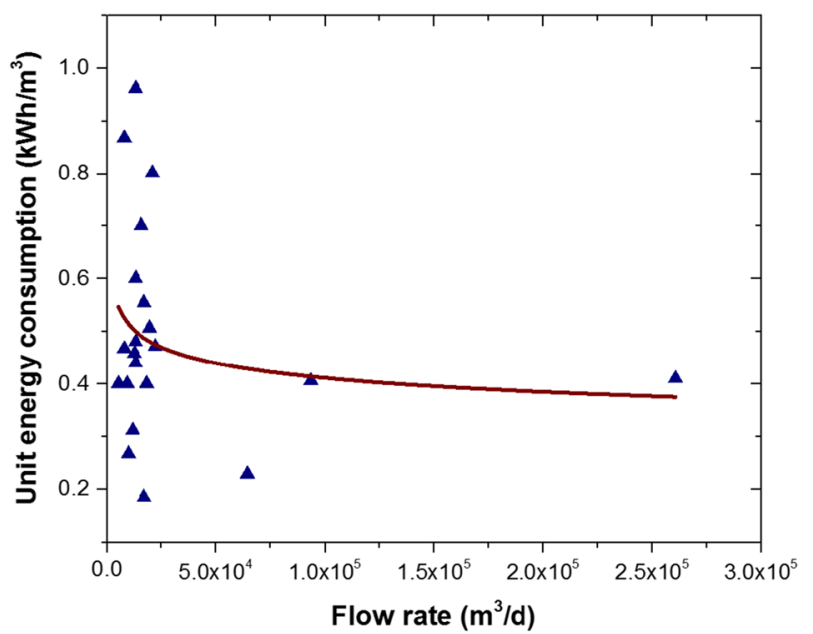

Fig. 3 Distribution of unit energy consumption with respect to annual average of treated wastewater inflow 
Table 2 Unit energy consumption of WWTPs with respect to different plant scales

\begin{tabular}{|c|c|c|c|c|c|c|c|}
\hline & \multicolumn{6}{|c|}{ Flow $\left(\mathrm{m}^{3} / \mathrm{d}\right) \times 10^{3}$} & \multirow[t]{2}{*}{ References } \\
\hline & $3.8-18.9$ & $18.9-37.8$ & $37.8-75.5$ & $75.5-189.3$ & $189.3-378.5$ & $>378.5$ & \\
\hline \multirow{5}{*}{$\begin{array}{l}\text { Energy } \\
\text { consumption } \\
\quad\left(\mathrm{kWh} / \mathrm{m}^{3}\right)\end{array}$} & 0.430 & 0.334 & 0.292 & 0.251 & 0.196 & 0.155 & Fillmore et al. 2011 \\
\hline & 0.392 & 0.375 & 0.371 & 0.372 & 0.372 & 0.372 & $\begin{array}{l}\text { Crawford and } \\
\text { Sandino } 2010\end{array}$ \\
\hline & 1.437 & 0.661 & 0.604 & 0.604 & 0.604 & 0.604 & Wisconsin 2016 \\
\hline & 0.591 & 0.362 & 0.318 & 0.294 & 0.278 & 0.272 & $\begin{array}{l}\text { Goldstein and } \\
\text { Smith } 2002\end{array}$ \\
\hline & 0.490 & 0.470 & - & - & - & - & This study \\
\hline
\end{tabular}

incoming plant load, and subsequently energy consumption trends were noticed during the past ten years. The plant has an anaerobic digester, which produces about 0.2 million $\mathrm{m}^{3}$ of biogas per year with the aid of a small scale in-situ boiler plant. The average unit energy consumption as function of treated wastewater volume was $0.46 \mathrm{kWh} / \mathrm{m}^{3}$, whereas, in terms of COD removal from wastewater, the load was $0.81 \mathrm{kWh} / \mathrm{kg}$ COD. As there was no electricity production in the plant, the energy self-sufficiency in electricity is $0 \%$. However, biogas was utilized to produce thermal heat, fulfilling most of the heating demand of the site, achieving almost $100 \%$ self-sufficiency in heat. The methane content of the biogas was assumed to be $60 \% \mathrm{CH}_{4}$ by volume (Remy et al. 2014) and the energy produced from biogas combustion was $0.222 \mathrm{kWh} / \mathrm{mol} \mathrm{CH}_{4}$ (Kim et al. 2011). The process-flow diagram including the unit energy consumptions of the major units of Mikkeli WWTP is shown in Fig. 4.

In the Mikkeli WWTP, the total energy consumption was 2,100,603 kWh/year with major energy shared by aeration, pumping and dewatering processes. The percentages of the aeration, pretreatment/dewatering, and lighting, including miscellaneous processes, were $30 \%, 34 \%$, and 36\%, repectively. The sludge age in Mikkeli WWTP is maintained normally at 15-25 days. Thus, the process is more close to conventional activated sludge process than extended aeration unit. Moreover, the mechanical aeration was equipped with energy efficient fine-bubble diffusers and highly efficient compressors controlled with variable frequency drives (VFDs).

\subsubsection{Energy Benchmarking of Mikkeli WWTP}

In energy benchmarking, unit energy consumption or specific energy consumption can be expressed as per cubic meter of treated water $\left(\mathrm{kWh} / \mathrm{m}^{3}\right)$, per unit of COD removed $(\mathrm{kWh} / \mathrm{kg}$ $\mathrm{COD}$ ), and per population equivalents ( $\mathrm{kWh} / \mathrm{PE} /$ year) (Vaccari et al. 2018). The most common parameter for defining the unit energy consumption in WWTPs is $\mathrm{kWh} / \mathrm{m}^{3}$. However, it is more likely that larger volume of wastewater are received in the WWTPs due to some factors such as stormwater flow, groundwater infiltrations, melting of ice to sewerage system that could possibly offers apparent energy discount due to higher denominator in the calculation of the $\mathrm{kWh} / \mathrm{m}^{3}$. Therefore, the unit energy consumption as a function of treated wastewater volume may be misleading due to diluted wastewater (Foladori et al. 2015). The unit energy consumption per unit of COD removed ( $\mathrm{kWh} / \mathrm{kg} \mathrm{COD})$ of both influent and effluent concentrations of COD can be more equivalent and suitable (Vaccari et al. 2018).

Therefore, the energy benchmarking of the Mikkeli WWTP as a function of COD removal was established by using the benchmark data provided by a guide to net-zero energy solutions 


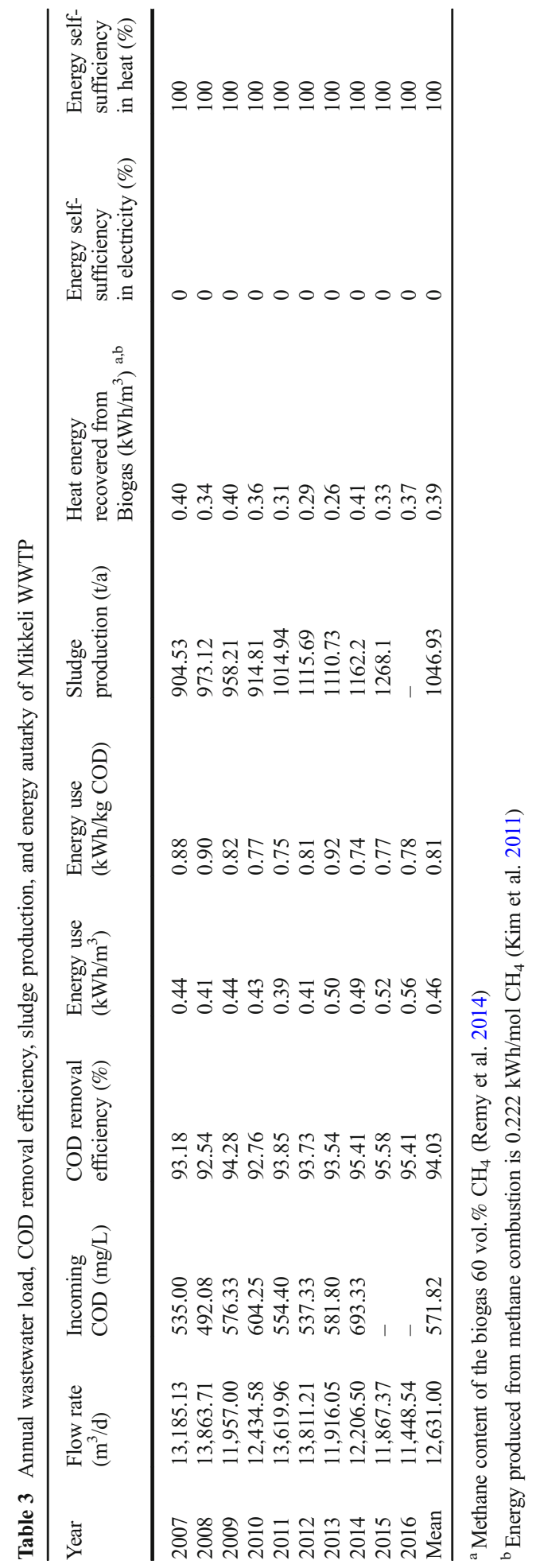




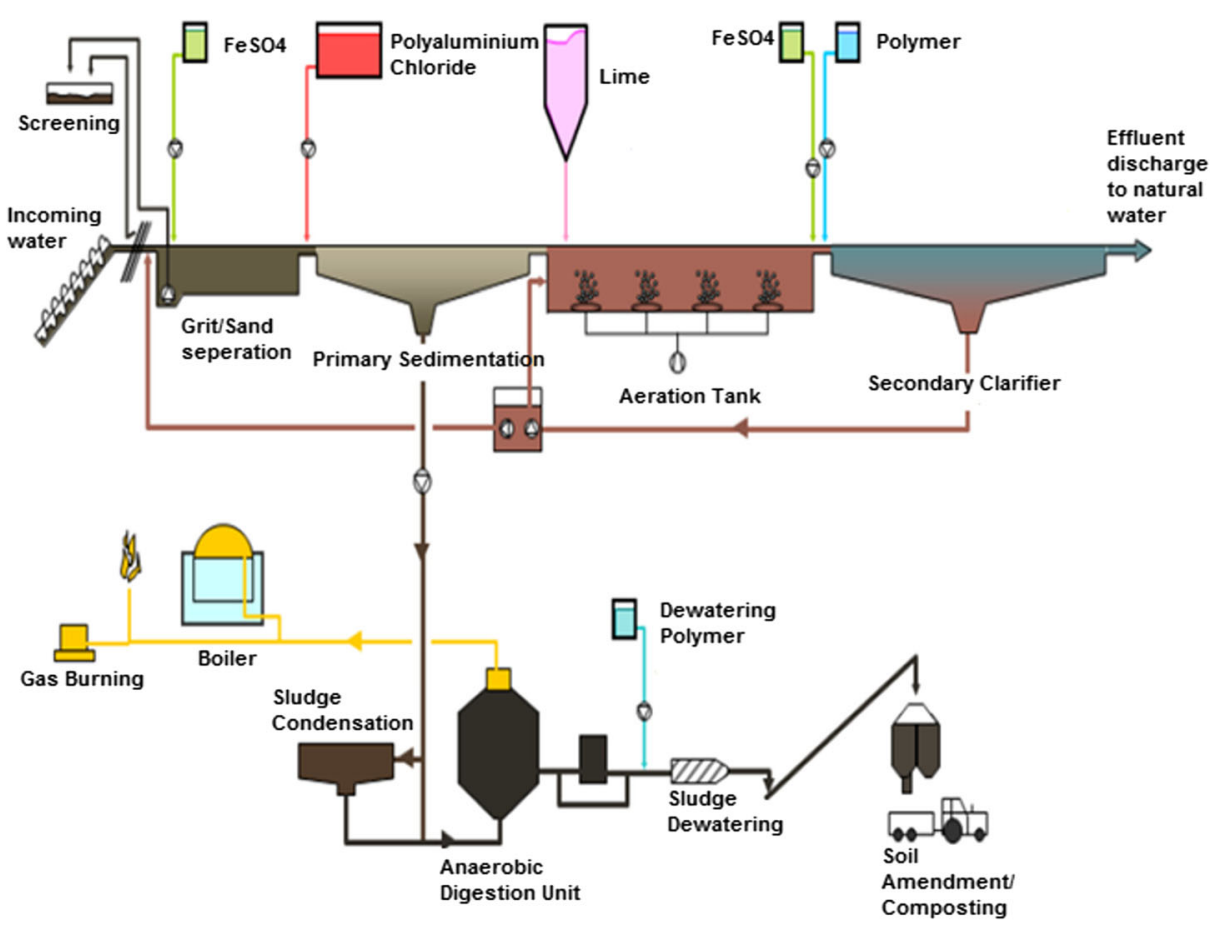

Fig. 4 Process-flow diagram of Mikkeli Wastewater Treatment Plant showing unit energy consumptions by major units (Source: Mikkeli WWTP)

for water resource recovery facilities (WRRFs) (Tarallo et al. 2015). The energy benchmarking data revealed major energy gaps in unit sections and a great potential of energy saving opportunities, as given in Table 4. The technical benchmark data of best practice (A1-B) configuration of Water Environment Research Foundation (WERF) was compared with baseline energy use of the case study WWTP. The net energy gap of $0.110 \mathrm{kWh} / \mathrm{kg}$ COD

Table 4 Energy benchmarking analysis of Mikkeli WWTP with respect to best available technical benchmark data

\begin{tabular}{|c|c|c|c|}
\hline \multirow[t]{2}{*}{ Unit processes } & \multicolumn{3}{|l|}{ Energy consumption (kWh/kg COD) } \\
\hline & $\begin{array}{l}\text { Baseline Energy at Mikkeli } \\
\text { WWTP based on A1-T } \\
\text { configuration (Tarallo et al. 2015) }\end{array}$ & $\begin{array}{l}\text { Best Practice (A1-B) } \\
\text { configuration (Tarallo } \\
\text { et al. 2015) }\end{array}$ & Energy gap \\
\hline Influent pump station & 0.126 & 0.119 & 0.006 \\
\hline Screening and grit removal & 0.037 & 0.008 & 0.029 \\
\hline Primary clarifiers & 0.008 & 0.008 & -0.002 \\
\hline Biological reactors and final clarifiers & 0.32 & 0.231 & 0.089 \\
\hline Disinfection & 0.02 & 0.002 & -0.001 \\
\hline Anaerobic digestion & 0.077 & 0.009 & 0.069 \\
\hline Dewatering & 0.005 & 0.007 & -0.002 \\
\hline Odor control & 0.00 & 0.242 & -0.242 \\
\hline Site lighting and miscellaneous & 0.228 & 0.064 & 0.163 \\
\hline Total & 0.802 & 0.692 & 0.110 \\
\hline
\end{tabular}


was estimated, which revealed a great potential to implement various retrofitting approaches to modify energy intensive Mikkeli WWTP into energy-positive WWTP. The major energy saving potentials at Mikkeli WWTP are attributed by $0.089 \mathrm{kWh} / \mathrm{kg}$ COD at biological reactors and final clarifiers, $0.029 \mathrm{kWh} / \mathrm{kg} \mathrm{COD}$ at screening and grit removal, and 0.006 $\mathrm{kWh} / \mathrm{kg} \mathrm{COD}$ at influent pump stations.

\subsection{Analysis of Emerging Technology Options for Retrofitting the Mikkeli WWTP to Energy Positive Operation}

The benchmarking analysis results indicate that there are great potentials of optimizing the energy consumption trends of the Mikkeli WWTP. Since the Mikkeli WWTP is an energy intensive municipal wastewater process based mainly on 'pollutant removal philosophy', energy positive operation is possible via the optimum use of chemical energy content of wastewater. The potential recovery of energy and valuable resources from wastewater can shift the paradigm of wastewater treatment to energy positive direction (McCarty et al. 2011; Verstraete et al. 2009). Domestic wastewater contains a significant amount of chemical energy in terms of chemical oxygen demand (COD, $\mathrm{mg}$ of $\mathrm{O}_{2} / \mathrm{L}$ ) (Gao et al. 2014; Gikas 2017; McCarty et al. 2011; Shoener et al. 2014; Yan et al. 2017).The organic energy contained in wastewater is approximately 9-10 times higher than that required to treat it (Hao et al. 2015; Yan et al. 2017). The chemical energy of wastewater embedded in organic matter could offset the energy requirements of CAS processes if only $40 \%$ of the total chemical energy is recovered from the wastewater. Therefore, a net energy-neutral or positive municipal wastewater treatment approach is realistic if the chemical energy in wastewater is effectively harnessed via innovative technologies (Meerburg et al. 2015). It is possible to retrofit the Mikkeli WWTP by adopting energy efficient technologies where major energy gap exists to achieve energy self-sufficiency. The proof of energy-positive WWTPs has already been experienced in many full-scale plants (Gu et al. 2017; Remy et al. 2014).

To aim this, an innovative configuration comprising four emerging technologies, i.e., (1) enhanced primary sedimentation, (2) staged anaerobic fluidized membrane bioreactor (SAFMBR), (3) completely autotrophic nitrogen removal over nitrite process (CANON), and (4) co-digestion of sewage sludge with organic waste, were evaluated to achieve energy selfsufficiency at the Mikkeli WWTP. The energy balance of four emerging technologies, based on unit energy produced per COD removal, is shown in Table 5. The net energy savings are estimated by taking into consideration all the energy expenses required for operating the unit processes of emerging technologies and the energy generated by methane gas and syn gas extracted from organic compounds (COD) of wastewater via either AnMBR or gasification. The proposed innovative energy positive retrofitted WWTP is shown in Fig. 5.

Enhanced primary solids removal technology based on microseiving (100-300 $\mu \mathrm{m}$ size) could significantly increase the energy recovery from biosolids either via anaerobic digestion or gasification (Gikas 2017; Remy et al. 2014). Microseiving can extract upto 65\% of the total organic load measured as COD in the sludge (Gikas 2017). Thus, enhanced primary sedimentation could produce sludge with a higher anaerobic digestibility than CAS sludge, and gasification of extracted organic matter could have higher net energy production potential compared to anaerobic digestion (Gikas 2017). The produced high quality syn gas from gasifier can produce $0.53 \mathrm{kWh} / \mathrm{kg}$ COD of electricity in CHP, whereas the electricity consumption for operating the microscreen, auger press is not higher than $0.02 \mathrm{kWh} / \mathrm{kg}$ COD. A net energy saving of $0.514 \mathrm{kWh} / \mathrm{kg}$ COD can be achieved. In subsequent step, the microseived 
Table 5 Energy balance of four emerging technologies to create energy-self-sufficiency at Mikkeli WWTP

\begin{tabular}{|c|c|c|c|c|c|c|c|}
\hline $\mathrm{SN}$ & Process & $\begin{array}{l}\text { Organic } \\
\text { load, } \\
\text { COD } \\
(\mathrm{mg} / \mathrm{L})\end{array}$ & $\begin{array}{l}\mathrm{COD} \\
\text { removed/ } \\
\text { inserted } \\
(\mathrm{mg} / \mathrm{L})\end{array}$ & $\begin{array}{l}\text { Energy } \\
\text { consumed } \\
(\mathrm{kWh} / \mathrm{kg} \\
\mathrm{COD})\end{array}$ & $\begin{array}{l}\text { Energy } \\
\text { produced } \\
(\mathrm{kWh} / \mathrm{kg} \\
\mathrm{COD})\end{array}$ & $\begin{array}{l}\text { Energy } \\
\text { saving } \\
(\mathrm{kWh} / \mathrm{g} \\
\mathrm{COD})\end{array}$ & References \\
\hline 1 & \multicolumn{7}{|c|}{ Enhanced Primary sedimentation } \\
\hline & Microsieving & 500 & 325 & 0.02 & 0.53 & 0.514 & Gikas 2017 \\
\hline \multirow[t]{2}{*}{2} & \multicolumn{7}{|c|}{ Anaerobic Membrane bioreactor (AnMBR) } \\
\hline & $\begin{array}{l}\text { Staged anaerobic fluidized } \\
\text { membrane bioreactor } \\
\text { (SAF-MBR) }\end{array}$ & 154 & 129.36 & 0.36 & 0.634 & 0.271 & Yoo et al. 2012 \\
\hline \multirow[t]{2}{*}{3} & \multicolumn{7}{|l|}{ Co-digestion } \\
\hline & $\begin{array}{l}\text { Co-digestion of sludge } \\
\text { with organic waste } \\
\text { (bio- waste) }\end{array}$ & $229900^{\mathrm{a}}$ & $6800^{\mathrm{b}}$ & - & 0.59 & 0.59 & $\begin{array}{l}\text { Zupančič } \\
\text { et al. } 2008\end{array}$ \\
\hline \multirow[t]{2}{*}{4} & \multicolumn{7}{|c|}{ Anaerobic ammonium oxidation (CANON) } \\
\hline & Anammox (CANON) & 1020 & 986.34 & $0.11^{\mathrm{c}}$ & $-{ }^{c}$ & -0.11 & Dai et al. 2015 \\
\hline
\end{tabular}

${ }^{\text {a }}$ Total COD load of organic waste (OW)

${ }^{\mathrm{b}}$ Total COD load of sludge (primary sludge + waste sludge + OW) (kg COD/day)

${ }^{\mathrm{c}}$ Energy consumed only by CANON MBR (No energy was recovered and used to treat high rate ammonia load from SAF-MBR + Co-digestion)

wastewater enters to SAF-MBR. The remaining organic load $(\sim 35 \%)$ can be further extracted in AnMBR process under anaerobic digestion. SAF-MBR alone could save maximum net energy of $0.271 \mathrm{kWh} / \mathrm{kg}$ COD via yield of biogas. On the other hand, the use of granular activated carbon (GAC) used for fluidized medium can support biological growth, thus helps positively in reducing membrane fouling (Kim et al. 2011). The total unit energy demand of $0.36 \mathrm{kWh} / \mathrm{kg}$ COD for combined SAF-MBR is quite less than that of secondary treatment processes in conventional WWTPs.

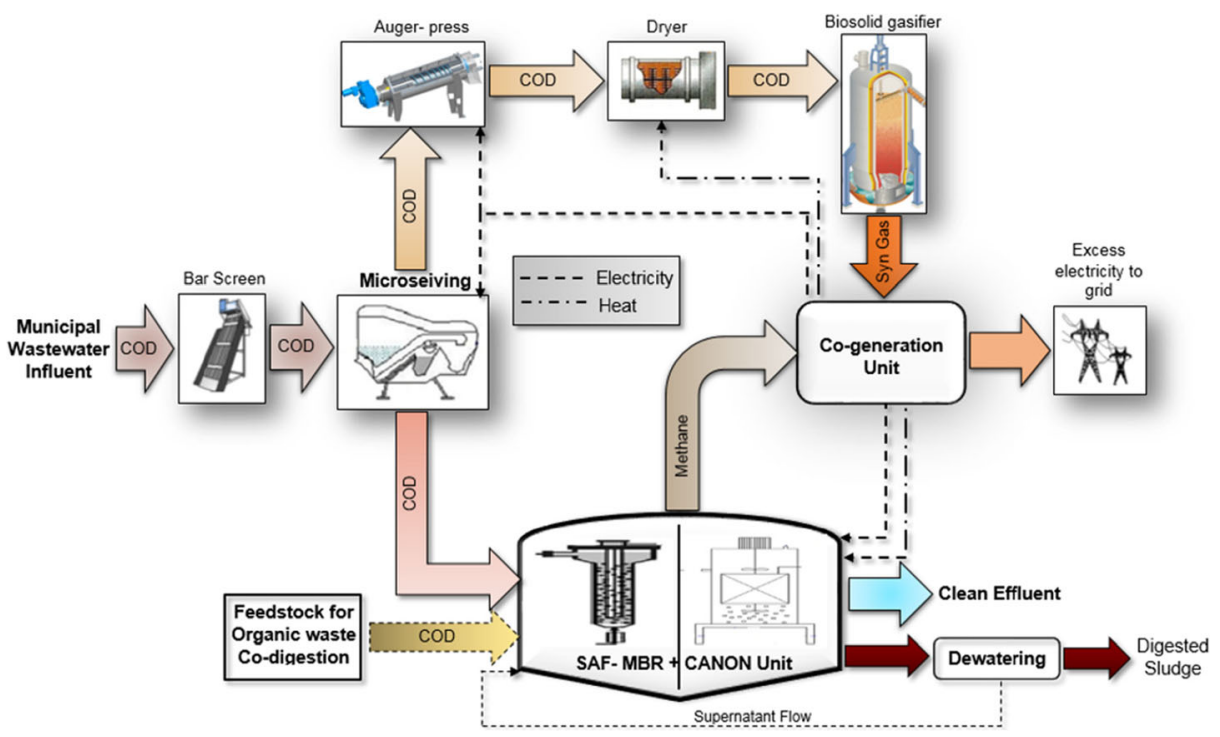

Fig. 5 A proposed innovative energy positive retrofitting technology for Mikkeli WWTP 
Meanwhile, the co-digestion of raw sludge with food waste can be a great opportunity to recover the potential of food waste as renewable energy (Koch et al. 2016). Co-digestion not only results in a higher methane yield, but also in higher rate of methane production. The onsite electricity production can be increased by 130-180\% of plant's own energy demand by co-digestion of food waste with wastewater sludge in ananerobic treatment (Zupančič et al. 2008). The electric energy production of $0.59 \mathrm{kWh} / \mathrm{kg}$ COD can be achieved when the total organic waste of $1700 \mathrm{~kg} / \mathrm{d}$ is co-digested with sludge (Zupančič et al. 2008). In co-digestion, degradation of organic waste could reach upto $100 \%$ with non-residual solids (Zupančič et al. 2008), which means that no excess sludge load is produced. However, one of the major disadvantages of co-digestion is the high nitrogen load reject water with reduced dewaterability (Koch et al. 2016). To treat the excess nitrogen load from rejected supernatant, a CANON-MBR process is proposed which further polishes the treated wastewater. CANON-MBR has revolutionized the removal of nitrogen from $\mathrm{NH}_{4}{ }^{+}$-rich residual streams in anoxic conditions with the aid of anammox bacteria (Dai et al. 2015). The anammox process has shown excellent performance in: reducing the aeration demand of conventional nitrification/denitrification by $60 \%$, decreasing $100 \%$ the organic carbon source demand and 90\% the sludge generation (Ali and Okabe 2015). The energy consumption of CANONMBR could be $0.11 \mathrm{kWh} / \mathrm{kg}$ COD, with the majority of expenses in biogas scouring and biological aeration. As the motive was to treat the digester supernatant with high rate of ammonia, no energy recovery was estimated. The removal of ammonia and total nitrogen can reach as high as 89 and $82 \%$, respectively (Dai et al. 2015).

As a result of estimating the net energy balance of four emerging retrofitting technologies, the maximum energy saving could reach as high as $1.26 \mathrm{kWh} / \mathrm{kg}$ COD. This energy saving is possible for overcoming the energy gap $(0.11 \mathrm{kWh} / \mathrm{kg}$ COD) of Mikkeli WWTP, providing a net positive energy surplus of $1.15 \mathrm{kWh} / \mathrm{kg}$ COD. From an energy perspective, the four emerging technologies have demonstrated a great deal of potential for retrofitting the Mikkeli WWTP into energy positive. However, several issues are still needed to be addressed and upgraded before its practical application in the future. Moreover, the capital cost for retrofitting technologies could be costly. The calculation of the captial cost for the construction of proposed energy-positive plant was not within the scope of this paper. However, achieving a breakeven point of the cost/benefit ratio might be possible within certain years because of the net surplus energy production from the retrofitted plant.

\section{Conclusions}

The paper concludes that the conventional Finnish wastewater facilities utilize energy intensive processes, and are commonly regarded as being only an energy sink. The statistical analysis of data from 22 WWTPs showed that the total energy consumption in Finnish WWTPs are positively correlated with inflow rate and sludge production. However, the unit energy consumption decreases with increasing capacity of plants. The energy benchmarking of the Mikkeli WWTP revealed an energy gap of $0.11 \mathrm{kWh} / \mathrm{kg}$ COD. The major energy saving potentials are attributed to secondary treatment, screening and grit removal, and influent pump stations. Four emerging technologies, such as enhanced primary sedimentation, staged anaerobic fludized membrane bioreactor, CANON MBR, and co-digestion of sludge with organic food waste were suggested as an innovative configuration based on maximum harnessing of chemical energy content in wastewater. The maximum energy savings could reach as high as 
$1.26 \mathrm{kWh} / \mathrm{kg}$ COD, which is possible for overcoming the energy gap of Mikkeli WWTP, providing net positive energy surplus of $1.15 \mathrm{kWh} / \mathrm{kg}$ COD.

Acknowledgements Authors would like to thank B. Anne, R. Risto, T. Esko, and P. Paula for providing the necessary database of energy consumptions in Mikkeli WWTP.

\section{Compliance with Ethical Standards}

Competing Interests The authors declare that they have no conflict of interests in relation to this work.

Open Access This article is distributed under the terms of the Creative Commons Attribution 4.0 International License (http://creativecommons.org/licenses/by/4.0/), which permits use, duplication, adaptation, distribution and reproduction in any medium or format, as long as you give appropriate credit to the original author(s) and the source, provide a link to the Creative Commons license and indicate if changes were made.

\section{References}

Ali M, Okabe S (2015) Anammox-based technologies for nitrogen removal: advances in process start-up and remaining issues. Chemosphere 141:144-153. https://doi.org/10.1016/j.chemosphere.2015.06.094

Belloir C, Stanford C, Soares A (2015) Energy benchmarking in wastewater treatment plants: the importance of site operation and layout. Environ Technol 36(2):260-269. https://doi.org/10.1080/09593330.2014.951403

Bodík I, Kubaská M (2013) Energy and sustainability of operation of a wastewater treatment plant. Environ Prot Eng 39(2):15-24

Crawford G, Sandino J (2010) Energy Efficiency in Wastewater Treatment in North America: A Compendium of Best Practices and Case Studies of Novel Approaches. IWA Publishing, London

Dai W, Xu X, Liu B, Yang F (2015) Toward energy-neutral wastewater treatment: a membrane combined process of anaerobic digestion and nitritation-anammox for biogas recovery and nitrogen removal. Chem Eng J 279: 725-734. https://doi.org/10.1016/j.cej.2015.05.036

Daw J, Hallett K, DeWolfe J, Venner I (2012) Energy efficiency strategies for municipal wastewater treatment facilities. Technical Report NREL/TP-7A30-53341. Office of Energy, U.S. Department of Energy. National Renewable Energy Laboratory, Golden

Dong X, Zhang X, Zeng S (2017) Measuring and explaining eco-efficiencies of wastewater treatment plants in China: an uncertainty analysis perspective. Water Res 112:195-207. https://doi.org/10.1016/j. watres.2017.01.026

European Union (EU) (2017) Standard method and online tool for assessing and improving the energy efficiency of wastewater treatment plants. Community Research and Development Information Service (CORDIS), 7-9

Fillmore L, Shaw A, Stone L, Tarallo S (2011) energy neutral wastewater treatment. In: Proceedings of the Water Environment Federation, LA, California, October 15-19, WEFTEC 2011, pp 630-641. https://doi. org/10.2175/193864711802639561

Foladori P, Vaccari M, Vitali F (2015) Energy audit in small wastewater treatment plants: methodology, energy consumption indicators, and lessons learned. Water Sci Technol 72(6):1007-1015. https://doi.org/10.2166 /wst.2015.306

Gao H, Scherson YD, Wells GF (2014) Towards energy neutral wastewater treatment: methodology and state of the art. Environ Sci-Proc Imp 16(6):1223-1246. https://doi.org/10.1039/C4EM00069B

Gikas P (2017) Towards energy positive wastewater treatment plants. J Environ Manag 203:621-629. https://doi. org/10.1016/j.jenvman.2016.05.061

Goldstein R, Smith W (2002) Water \& sustainability: U.S. electricity consumption for water supply \& treatment the next half century. Water Supply, 4(Volume 4), 93

Gu Y, Li Y, Li X, Luo P, Wang H, Robinson ZP, Wang X, Wu J, Li F (2017) The feasibility and challenges of energy self-sufficient wastewater treatment plants. Appl Energy 204:1463-1475. https://doi.org/10.1016/j. apenergy.2017.02.069

Gurung K, Ncibi MC, Fontmorin J, Särkkä H, Sillanpää M (2016) Incorporating submerged MBR in conventional activated sludge process for municipal wastewater treatment : a feasibility and performance assessment. J Membr Sci Technol 6(3). https://doi.org/10.4172/2155-9589.1000158 
Hahn MJ, Figueroa LA (2015) Pilot scale application of anaerobic baffled reactor for biologically enhanced primary treatment of raw municipal wastewater. Water Res 87:494-502. https://doi.org/10.1016/j. watres.2015.09.027

Haimi H, Mulas M, Sahlstedt K, Vahala R (2009) Advanced operation and control methods of municipal wastewater treatment processes in Finland, Helsinki University of Technology, Water and Wastewater Engineering, Helsinki, pp. 45-48

Hao X, Liu R, Huang X (2015) Evaluation of the potential for operating carbon neutral WWTPs in China. Water Res 87:424-431. https://doi.org/10.1016/j.watres.2015.05.050

Kartal B, Kuenen JG, Loosdrecht MCMC (2010) Sewage treatment with anammox. Science 328(5979):702703. https://doi.org/10.1126/science.1185941

Katuri KP, Werner CM, Jimenez-Sandoval RJ, Chen W, Jeon S, Logan BE, Lai Z, Amy GL, Saikaly PE (2014) A novel anaerobic electrochemical membrane bioreactor (AnEMBR) with conductive hollow-fiber membrane for treatment of low-organic strength solutions. Environ Sci Technol 48(21):12833-12841. https://doi. org/10.1021/es504392n

Kim J, Kim K, Ye H, Lee E, Shin C, McCarty PL, Bae J (2011) Anaerobic fluidized bed membrane bioreactor for wastewater treatment. Environ Sci Technol 45(2):576-581. https://doi.org/10.1021/es1027103

Koch K, Plabst M, Schmidt A, Helmreich B, Drewes JE (2016) Co-digestion of food waste in a municipal wastewater treatment plant: comparison of batch tests and full-scale experiences. Waste Manag 47:28-33. https://doi.org/10.1016/j.wasman.2015.04.022

Lauwers J, Appels L, Taes S, Van Impe J, Dewil R (2012) Anaerobic co-digestion of fats, oils and grease (FOG) with waste activated-sludge, PRES 2012: 15th International Conference on Process Integration, Modelling and Optimisation for Energy Saving and Pollution Reduction, Italian Association of Chemical Engineering AIDIC, Prague, Czech Republic, Aug 25-29, Vol. 29, pp. 709 - 714, Chemical Engineering Transactions, https://lirias.kuleuven.be/handle/123456789/359467

McCarty PL, Bae J, Kim J (2011) Domestic wastewater treatment as a net energy producer-can this be achieved? Environ Sci Technol 45(17):7100-7106. https://doi.org/10.1021/es2014264

Meerburg FA, Boon N, Winckel TV, Vercamer JAR, Nopens I, Vlaeminck SE (2015) Toward energy-neutral wastewater treatment: a high-rate contact stabilization process to maximally recover sewage organics. Bioresour Technol 179:373-381. https://doi.org/10.1016/j.biortech.2014.12.018

Metcalf and Eddy (2003) Wastewater Engineering: Treatment and Reuse. McGraw-Hill

Mizuta K, Shimada M (2010) Benchmarking energy consumption in municipal wastewater treatment plants in Japan. Water Sci Technol 62(10):2256-2262. https://doi.org/10.2166/wst.2010.510

Nowak O, Enderle P, Varbanov P (2015) Ways to optimize the energy balance of municipal wastewater systems: lessons learned from Austrian applications. J Clean Prod 88:125-131. https://doi.org/10.1016/j. jclepro.2014.08.068

Remy C, Boulestreau M, Lesjean B (2014) Proof of concept for a new energy-positive wastewater treatment scheme. Water Sci Technol 70(10):1709-1716. https://doi.org/10.2166/wst.2014.436

Rodriguez-Garcia G, Molinos-Senante M, Hospido A, Hernández-Sancho F, Moreira MT, Feijoo G (2011) Environmental and economic profile of six typologies of wastewater treatment plants. Water Res 45(18): 5997-6010. https://doi.org/10.1016/j.watres.2011.08.053

Scherson YD, Criddle CS (2014) Recovery of freshwater from wastewater: upgrading process configurations to maximize energy recovery and minimize residuals. Environ Sci Technol 48(15):8420-8432. https://doi. org/10.1021/es501701s

Shen Y, Linville JL, Urgun-Demirtas M, Mintz MM, Snyder SW (2015) An overview of biogas production and utilization at full-scale wastewater treatment plants (WWTPs) in the United States: challenges and opportunities towards energy-neutral WWTPs. Renew Sust Energ Rev 50:346-362. https://doi.org/10.1016/j. rser.2015.04.129

Shoener BD, Bradley IM, Cusick RD, Guest JS (2014) Energy positive domestic wastewater treatment: the roles of anaerobic and phototrophic technologies. Environ Sci-Proc Imp 16(6):1204-1222. https://doi.org/10.1039 /C3EM00711A

Singh P, Carliell-Marquet C, Kansal A (2012) Energy pattern analysis of a wastewater treatment plant. Appl Water Sci 2(3):221-226. https://doi.org/10.1007/s13201-012-0040-7

Tang WZ, Sillanpää M (2018) Sustainable Environmental Engineering. WILEY, New York, pp 50130-50130

Tarallo S, Shaw A, Kohl P, Eschborn R (2015) A guide to net-zero energy solutions for water resource recovery facilities- energy solutions for water. Water Environment Research Foundation (WERF). Alexandria,VA

US EPA, NSF, US DOE (2015) Energy-positive water resource recovery workshop report. Workshop Date: April 28-29, 2015, Arlington, VA

USEPA (2010) Evaluation of energy conservation measures for wastewater treatment facilities. EPA-832-R-10005. September 2010. US Environmental Protection Agency. Washington, DC. https://nepis.epa.gov. Accessed 3 February 2018 
Vaccari M, Foladori P, Vitali F (2018) Benchmarking of energy consumption in municipal wastewater treatment plants - a survey of over 200 plants in Italy. Water Sci Technol: wst2018035. https://doi.org/10.2166 /wst.2018.035

Verstraete W, Caveye PVD, Diamantis V (2009) Maximum use of resources present in domestic "used water". Bioresour Technol 100(23):5537-5545. https://doi.org/10.1016/j.biortech.2009.05.047

Wang X, Liu J, Ren N-Q, Yu H-Q, Lee D-J, Guo X (2012) Assessment of multiple sustainability demands for wastewater treatment alternatives: a refined evaluation scheme and case study. Environ Sci Technol 46(10): 5542-5549. https://doi.org/10.1021/es300761x

Wisconsin (2016). Energy best practices guide : water \& wastewater industry. Focus on Energy. https://focusonenergy.com. Accessed 7 Feb 2018

Yan P, Qin R, Guo J, Yu Q, Li Z, Chen Y-P, Shen Y, Fang F (2017) Net-zero-energy model for sustainable wastewater treatment. Environ Sci Technol 51(2):1017-1023. https://doi.org/10.1021/acs.est.6b04735

Yoo R, Kim J, McCarty PL, Bae J (2012) Anaerobic treatment of municipal wastewater with a staged anaerobic fluidized membrane bioreactor (SAF-MBR) system. Bioresour Technol 120:133-139. https://doi. org/10.1016/j.biortech.2012.06.028

Zupančič GD, Uranjek-Ževart N, Roš M (2008) Full-scale anaerobic co-digestion of organic waste and municipal sludge. Biomass Bioenergy 32(2):162-167. https://doi.org/10.1016/j.biombioe.2007.07.006 